\title{
The role of discretionary accruals in earnings management: Evidence from Tehran Stock Exchange
}

\author{
Mehdi Maranjory $^{a^{*}}$, Razieh Alikhani ${ }^{\mathrm{a}}$, Abdullah Zabihzadeh ${ }^{\mathrm{b}}$ and Petro Sepehri $^{\mathrm{c}}$
}

${ }^{a}$ Department of Accounting, Chalous Branch, Islamic Azad University (IAU), Chalous, Iran

${ }^{b}$ Department of Accounting, Shomal Branch, Amol, Iran

${ }^{c}$ Department of Accounting, Astara Branch, Islamic Azad University (IAU), Astara, Iran

\section{H R O N I C L E}

\section{Article history:}

Received May 12, 2013

Received in revised format

12 August 2013

Accepted 18 August 2013

Available online

August 192013

Keywords:

Earnings management

Discretionary accruals

Tehran Stock Exchange

\begin{abstract}
A B S T R A C T
Earnings management via discretionary accruals is a manager's instrument for changing stock holders' expectations. The purpose of this study is to investigate the role of discretionary accruals in the earnings management of Iranian firms. There are two hypotheses associated with this study on the relationship between income smoothness and discretionary accruals and the proposed study is implemented on selected firms from Tehran Stock Exchange. The result of the first hypothesis indicates the relationship between earnings smoothness and discretionary accruals variables. It means that discretionary accruals (DA) leads to the converse relationship among discretionary accruals variation and current and future cash flow. The result of the second hypothesis indicates that the firms with high variation in Iran utilize more discretionary accruals compared with the firms with lower variation.
\end{abstract}

C 2013 Growing Science Ltd. All rights reserved.

\section{Introduction}

These days, investors require more information in addition to official financial statements about income to make sound investment decisions. Therefore, proved information about the majority of firms especially Initial public offerings (IPOs) is not accessible to public; and it also includes the ability to use incentive accountings and earnings management procedures via discretionary accruals. The manager's instrument to alter stockholders expectation includes earnings management via discretionary accruals. Discretionary accruals contain that part of the accruals income is different from operational cash flow that is imposed in accounts due to the accounting methods adopted by the management. It is obvious that the firms dealing with income smoothing are recognizable; and the size and volume of discretionary accruals can be determined. For instance, if in this year, the accruals income is less than the previous year, the management will be able to increase income via 
discretionary accruals. If accruals income is greater than the previous year, the managers may adopt a kind of method to transfer the accruals to future periods in order to adjust current earnings, increase future earnings, and negatively report discretionary accruals in the current year. In converse, if the firm is smoothing and its earnings without discretionary accruals is less than income of the previous year, it will be expected that the discretionary accruals in the current year to be positive. In addition, it is also expected that higher level smoothing firms demonstrate their purpose via reporting their discretionary accruals. On this basis, the theoretical foundation for the research hypothesis has been provided.

\section{Literature Review}

Teoh et al. (1998) revealed that discretionary accruals are considerably high in the year when a firm offers its stock for the first time (IPO), and it is negatively concerned with the future net income and operational cash flow. They conducted a research to focus stock price after initial public offerings in the subsequent years and concluded that discretionary accruals and operation were negatively related. On the other hand, they found out that the firms positively reporting discretionary accruals after IPO had low prices. It means that those firms, which were not able to have their predicted expected earnings before IPO during the next three years would make use of discretionary accruals after IPO. This requires the reduction of price after it is revealed.

Subramanyam (1996) claimed that market connects the value of the firm with discretionary accruals to predict discretionary accruals, future earnings and variation in stock income. Teoh et al. (1998) pointed out that IPO smoothing firms manage their earnings via discretionary accruals. In fact, there is a significant converse relationship among the discretionary accruals, future net, and cash flow variations. Based on their findings, the discretionary accruals were in a high rank in the year when the firm offered its stock for the first time; and the accruals had negative relationship with future net income and operational cash flows. Conducting a research on the stock price from operation in the years after the initial public offerings, Sloan (1996) found out that earnings continuity in a firm depends on the relative importance of its cash components and earnings accrual. If investors cannot differentiate these two components of accounting income, they will definitely make a mistake. In this experiment, when he found out that stock prices were not totally under the impact of discretionary accruals or cash flow and investors are not capable of analyzing its effects on stock price, his idea regarding the reduction of earnings continuity due to increase in discretionary accruals and increase due to cash flow increase, was rejected. Chan et al. (2001) conducted a research on the relationship between discretionary accruals and future stock return. The results showed that stock return in the firms having higher discretionary accruals was reduced in the period after reporting current period. It means that having qualified with lower earnings, firms receive low return.

Kenan (2001) reported that the more earnings is close to cash flow, the less the discretionary accruals. As a result, the earnings will be highly-qualified. Therefore, the return of the future period will be more. If the quality of the earnings is lower, the future stock return will also be less, however. Dechow et al. (1995) found out that nondiscretionary accruals are fixed and they are not supposed to be used for smoothing earnings. Additionally, earnings managements occur due to discretionary accruals. Barton and Simko (2002) pointed out that earnings management in the subsequent periods depends on the type and amount of discretionary accruals which has been used in preceding years, since the effect of discretionary accruals dates back to the past. Gosh and Olsen (2009) conducted a research showing that the managers make use of discretionary accruals for reducing earnings frequency.

\section{Research Hypothesis and Models Analysis for the Tests}

$\mathrm{H}_{1}$. Initial public offerings (IPO) are more concerned with reporting discretionary accruals and these accruals have converse relationship with the difference between current year earnings and preceding year's earnings. 
$\mathrm{H}_{2}$. Initial public offerings (IPO) are more concerned with reporting discretionary accruals and these accruals have a direct relationship with variance ratio (after considering the difference between current and preceding year's earnings). For testing the first and second hypothesis of the research and in order to study the relationship between smoothness using discretionary accruals, the following model has been provided.

$D A_{i t}=\beta_{0}+\beta_{1} F_{i}+\beta_{2} \ln \left(V R_{i}\right)+\beta_{3}\left(F_{i} \times \ln \left(V R_{i}\right)\right)+e_{i t}$

In Eq. (1), $F_{i}$ is a dummy variable and it is one when cache flow from operation and discretionary accruals is higher than end of the year earnings, and zero, otherwise. In this model, $D A$ (discretionary accruals) is calculated as follows:

$D A_{i t}=T A_{i t}-N D A_{i t}$

where $T A_{i t}$ is total accruals and $N D A_{i t}$ is non-discretionary accruals, $T A_{\text {it }}$ is calculated as follows:

$T A=N I_{i t}-C F_{i t}$

where $N I_{i t}$ shows net income in the third year and $C F_{i t}$ is cash flow from operation in the third year of the firm function. Non-discretionary accruals will be calculated as follows:

$$
\begin{aligned}
& \frac{\operatorname{TA}_{i t}}{\operatorname{ASSETS}_{i, t}}=b_{1 j} \frac{1}{\operatorname{ASSETS}_{i, t-1}}+b_{2 j} \frac{\Delta \operatorname{SALES}_{i t}}{\operatorname{ASSETS~}_{i, t-1}}+b_{3 j} \frac{\operatorname{GPPE}_{i t}}{\operatorname{ASSETS}_{i, t-1}} \\
& \operatorname{NDA}_{i t}=\beta_{1 j} \frac{1}{\operatorname{ASSETS~}_{i, t-1}}+\beta_{2 j} \frac{\Delta S A L E S_{i t}}{\operatorname{ASSETS~}_{i, t-1}}+\beta_{3 j} \frac{\operatorname{GPPE}_{i t}}{\operatorname{ASSETS~}_{i, t-1}}
\end{aligned}
$$

The coefficients of $\beta_{1 \mathrm{j}}, \beta_{2 \mathrm{j}}$ and $\beta_{3 \mathrm{j}}$ are obtained based on regression techniques. In order to explain the above mentioned coefficients in Hypothesis 1, it should be mentioned that if IPO needs to positively employ income smoothness, that is, current earning is less than annual earning, $F_{i}=0$ and the coefficients of $\beta_{1}, \beta_{3}$ should be positive. Conversely, if IPO needs to negatively employ income smoothness, that is, current earning is more than annual earning of the preceding year, $F_{i}=1$ and the coefficients of $\beta_{1}$ and $\beta_{2}$ should be negative; and their absolute ratio need to be more than $\beta_{1}$ and $\beta_{2}$.

The regression coefficient obtained in Hypothesis 2 will be interpreted as follows: if $\beta_{2}$ is negative and $\beta_{3}$ is positive, it shows that, in smoothing firms, discretionary accruals are in the same direction as income smoothness.

\section{Research Method}

This study is an archival research. Panel Data method is employed as technique to estimate the relationship between Discretionary Accruals with Earnings Management. Sample used in this research includes financial data for 51 firms listed in the Tehran Stock Exchange over the period 2006-2010. Each company had to meet specific criteria to be included in the sample:

1. They must close their fiscal year on mid-March (end of Persian calendar).

2. They must have full financial data for the whole period of investigation.

The data needed for analysis are collected from the database associated with the Islamic Research Management Center of the Tehran Exchange Market.

\section{Data Analysis Methods}

In order to test and analyze the hypotheses, Multiple Variation Regression Analysis was used and the significance of the models is evaluated by using the statistical tests of $\mathbf{T}$ and $\mathbf{F}$. 
In order to test the research hypotheses, it was required to categorize the sample firms under the study into High and Low Smoothing Firms. To do so, first, the ratio of operational activities variance to the net income variance (which is called VRi) was calculated. Then, based on the median, High and Low Smoothing Firms were classified.

$$
V R_{i t}=\frac{\operatorname{Var}\left(C F_{i t}\right)}{\operatorname{Var}\left(N I_{i t}\right)},
$$

where $V R_{i}$ Ratio (variance ratio) is an index used to distinguish smoothing firms from non-smoothing firms by using the central tendency of median; and the numbers above the median were classified as High Smoothing Firms and the numbers under the median as Low Smoothing Firms. It should be mentioned that Smoothing Index was three years after initial public offerings. In the above mentioned equation, $\operatorname{Var}(\mathrm{CFit})$ is cash flow variance from operation and Var (NIit) is net income variance.

\section{Research Findings}

\section{The result of hypothesis 1:}

The following regression model has been used in order to respond to the first hypothesis. Table 1 illustrates the results:

$$
D A_{i}=\beta_{0}+\beta_{1} F_{i}+\beta_{2} L N\left(V R_{i}\right)+\beta_{3}\left(F_{i} * L N\left(V R_{i}\right)\right)+e_{i}
$$

\section{Table 1}

The results of ANOVA test

\begin{tabular}{lllllll}
\hline Model & Sum Squares & df & Mean Square & $\mathrm{R}^{2}$ & $\mathrm{~F}$ & \multicolumn{2}{c}{ Sig } \\
\cline { 1 - 4 } Regression & 6.289 & 3 & 2.096 & & & \\
Residual & 6.711 & 48 & 0.140 & 0.484 & 14.994 & 0.000 \\
\hline Total & 13.000 & 51 & & & & \\
\hline
\end{tabular}

The first hypothesis shows the relationship between income smoothness and discretionary accruals. In order to test this hypothesis, the null hypothesis and hypothesis 1, will be defined as follows:

$\mathrm{H}_{0}$ : There is no significant relationship between income smoothness and discretionary accruals.

$\mathrm{H}_{1}$ : There is a significant relationship between income smoothness and discretionary accruals.

$$
\begin{aligned}
& \mathrm{H}_{0}: \beta \leq 0 \\
& \mathrm{H}_{1}: \beta>0
\end{aligned}
$$

As it was indicated in Table 1, the regression is significant. Regarding the amount of $\mathbf{R}^{2},(0.484)$ and the results of variance analysis and obtained $\mathbf{F}$ (14.994) and the significance value (0.000), it can be concluded that statistically error variance is significantly less than 0.01 and the regression is reliable. As a result, smoothness has a direct relationship with discretionary accruals and, in turn, these accruals are conversely related to the differences between current year earnings and preceding year earnings. In Table 1 , the coefficient specification of $\mathbf{R}^{\mathbf{2}}$ shows that the variable of LNVRi explains approximately 48 percent of the dependent variables and the remaining 52 percent are explained by the factors other than LNVRi.

Table 2

Regression Coefficient Predicting Discretionary Accruals

\begin{tabular}{llllll}
\hline Model & B & Std.Error & Beta & t & Sig \\
\hline Constant & 15043.757 & 16573.930 & - & 0.908 & 0.365 \\
Fi & -17447.295 & 23194.160 & -0.05 & -0.752 & 0.453 \\
LNVRi & -28600.087 & 8589.718 & -0.237 & -3.300 & $0.001^{*}$ \\
Fi LN(VRi) & 31903.953 & 15679.110 & 0.153 & 2.035 & 0.043 \\
\hline
\end{tabular}


Table 2 demonstrates that the $T$ statistics places in the critical area. The null hypothesis with the probability of $95 \%$ is rejected. The sig value also indicates that the null hypothesis with $95 \%$ reliability is rejected. As a result, hypothesis 1 is accepted, and as a result, there is a significant relationship between income smoothness and discretionary accruals in Tehran stock firms. Table 2 also shows that among the dependent variables used in this model, only the interference of LN(VRi) in regression model is significant, but the other variables with $95 \%$ reliability are not significant.

\section{The Results of Hypothesis 2}

In order to respond to the second hypothesis in this study, the following regression model has been used. The results are shown in Table 3.

$$
\mathrm{DA}_{\mathrm{i}}=\beta_{0}+\beta_{1} \mathrm{~F}_{\mathrm{i}}+\beta_{2} \mathrm{LN}\left(\mathrm{VR}_{\mathrm{i}}\right)+\beta_{3}\left(\mathrm{~F}_{\mathrm{i}} \times \mathrm{LN}\left(\mathrm{VR}_{\mathrm{i}}\right)\right)+\mathrm{e}_{\mathrm{i}}
$$

\section{Table 3}

The results of the analysis of regression significance variance

\begin{tabular}{lllllll}
\hline Model & Sum Squares & df & Mean Square & $\mathrm{R}^{2}$ & $\mathrm{~F}$ & Sig \\
\hline Regression & 6.289 & 3 & 2.096 & & & \\
Residual & 6.711 & 48 & 0.140 & 0.484 & \multirow{2}{*}{14.994} & 0.000 \\
\cline { 1 - 4 } & 13.000 & 51 & & & & \\
\hline
\end{tabular}

The second hypothesis studies the relationship between income smoothness and discretionary accruals. To test this hypothesis, the null hypothesis and hypothesis 1 will be defined as follows:

$\mathbf{H}_{\mathbf{0}}$ : There is no relationship between income smoothness and discretionary accruals. $\mathrm{H}_{0}: \beta \leq 0$

$\mathbf{H}_{1}$ : There is a relationship between income smoothness and discretionary accruals. $\mathrm{H}_{1}: \beta>0$

In other words, as it is shown in Table 3 , the sig value is 0.000 which shows that $p<0.05$. It indicates that the null hypothesis claiming that there is no relationship between income smoothness and discretionary accruals is rejected. Therefore, $\mathrm{H}_{1}$ claiming that there was a relationship between income smoothness and discretionary accruals is accepted. Accordingly, there was statistically a significant relationship between income smoothness and discretionary accruals, $F(3,48)=14.994, p=$ $0.000, \mathbf{R}^{2}=0.484$. Because $p<0.05$, and regression is reliable, so it can be concluded that, there is a relationship between income smoothness and discretionary accruals. It means that discretionary accruals $\left(\mathrm{DA}_{\mathrm{i}}\right)$ has a direct relationship with the ratio of variance (VRi). As a result, High variation firms make more use of discretionary accruals compared to Low discretionary accruals. $\mathbf{R}^{2}$ demonstrates that LNVRi variable explains approximately about $48 \%$ of the dependent variables; and the remaining $52 \%$ are explained by the factors other than LNVRi.

\section{Table 4}

Regression coefficient predicting discretionary accruals

\begin{tabular}{llllll}
\hline Model & B & Std.Error & Beta & T & Sig \\
\hline Constant & 15043.757 & 16573.930 & - & 0.908 & 0.365 \\
Fi & -17447.295 & 23194.160 & -0.05 & -0.752 & 0.453 \\
LNVRi & -28600.087 & 8589.718 & -0.237 & -3.300 & 0.001 \\
\hline Fi LN(VRi) & 31903.953 & 15679.110 & 0.153 & 2.035 & 0.043 \\
\hline
\end{tabular}

In Table 4 it was indicated that $\mathrm{T}$ statistics is in critical area and null hypothesis (H0) with the probability of $95 \%$ is rejected. Sig value was calculated, it points out that null hypothesis is also rejected with reliability of $95 \%$. 


\section{Conclusions}

In this paper, we have presented an empirical investigation to study how well it is possible to manage earnings via discretionary and nondiscretionary accruals. The study of volume and size of discretionary accruals could be led to the finding of income smoothness and its amount in IPO. Thus, discretionary accruals (DA) and variation ratio (VA) were directly related, that is, high variation firms made use of discretionary accruals compared to Low variation firms.

The first hypothesis $\left(\mathrm{H}_{1}\right)$ showed the relationship between the income smoothness and discretionary accruals, that is in IPO, discretionary accruals required the converse relationship among discretionary accruals, cash flow, and future earnings variables. Therefore, in IPO, discretionary accruals were positive, showed that this number had converse relationship with the current year earnings and preceding year earnings differences. Thus it was expected that there should also be a converse relationship between cash flow from operation and discretionary accruals. The results of this study were in line with the findings of Teoh et al. (1998) and Dechow et al. (1995).

The second test, which had been run on the second Hypothesis $(\mathrm{H} 2)$ demonstrated that there was a direct relationship between discretionary accruals (DAi) and Variance ratio (VRi). It indicated that High variation firms compared with Low variation firms, made more use of discretionary accruals. As a result, in IPO discretionary accruals were positive and showed direct relationship with variation ratio (VRi). The findings of this hypothesis were in line with Teoh et al. (1995) and Dechow et al (1995).

\section{References}

Barton, J., \& Simko, P. J. (2002). The balance sheet as an earnings management constraint. The Accounting Review, 77(s-1), 1-27.

Chan, K., Chan, L. K., Jegadeesh, N., \& Lakonishok, J. (2001). Earnings quality and stock returns (No. w8308). National Bureau of Economic Research.

Dechow, P. M., Sloan, R. G., \& Sweeney, A. P. (1995). Detecting earnings management. Accounting Review, 70, 193-225.

Dechow, P. M., Sloan, R. G., \& Sweeney, A. P. (1996). Causes and consequences of earnings manipulation: An analysis of firms subject to enforcement actions by the sec. Contemporary accounting research, 13(1), 1-36.

Ghosh, D., \& Olsen, L. (2009). Environmental uncertainty and managers' use of discretionary accruals. Accounting, Organizations and Society, 34(2), 188-205.

Teoh, S. H., Welch, I., \& Wong, T. J. (1998). Earnings management and the long-run market performance of initial public offerings. The Journal of Finance,53(6), 1935-1974.

Kenan. C. (2001). Earning quality and stock Return, working paper, National Taiwan university Department of Finance.

Sloan, R. G. (1996). Do stock prices fully reflect information in accruals and cash flows about future earnings?. Accounting Review, 71(3), 289-315.

Subramanyam, K. R. (1996). The pricing of discretionary accruals. Journal of accounting and economics, 22(1), 249-281. 